\title{
PURWARUPA PENYIRAMAN OTOMATIS DENGAN ARSITEKTUR MQTT DAN LOGIKA FUZZY SUGENO UNTUKMENINGKATKAN KEEFEKTIFAN MANAJEMEN PENYIRAMAN TANAMAN (STUDI KASUS : ITERA)
}

\author{
Muhamad Arwin Wijaya), Raidah Hanifah' ${ }^{2)}$, dan Martin Clinton Tosima Manullang ${ }^{3)}$ \\ 1, 2,3) Teknik Informatika Institut Teknologi Sumatera \\ Jl. Terusan Ryacudu, Way Huwi, Kec. Jati Agung, Kabupaten Lampung Selatan, Lampung \\ e-mail: muhamad.14116050@student.itera.ac.id ${ }^{1}$, raidah.hanifah@if.itera.ac.id ${ }^{2}$, martin.manullang@ if.itera.ac.id ${ }^{3)}$
}

\begin{abstract}
ABSTRAK
ITERA merupakan kampus dengan slogan smart, friendly and forest campus. Kampus hijau (forest campus) dapat diwujudkan dengan melakukan penyiraman secara rutin pada tanaman. Ketika penyiraman tanaman tersebut tidak mencukupi maka tanaman akan layu dan mati, namun air yang berlebihan juga menyebabkan tanaman tidak dapat tumbuh karena terjadi pembusukan pada akar tanaman. Sistem penyiraman otomatis yang dapat memantau kondisi lingkungan tanaman dengan menggunakan protokol MQTT dapat dirancang sebagai sistem yang dapat memantau kondisi lingkungan tanaman secara jarak jauh dan waktu nyata. Sistem ini dibuat menggunakan sensor DHT11 yang berfungsi untuk membaca suhu dan juga sensor YL-69 yang berfungsi untuk membaca kelembaban tanah. DHT11 membaca suhu dengan nilai antara $0-50$ C dengan rata-rata nilai error $2.22 \%$. Semakin tinggi nilai output sensor suhu maka suhu akan semakin panas, apabila nilai output sensor suhu semakin rendah maka suhu akan semakin dingin. Untuk sensor YL-69 dapat membaca nilai dari kelembaban tanah yang memiliki rentang antara 0 - 1023 dengan rata-rata nilai error 11.09\%. Semakin tinggi nilai output sensor kelembapan tanah maka kondisi tanah akan semakin kering, apabila nilai output sensor kelembaban tanah semakin rendah maka kondisi tanah semakin lembap. Sensor tersebut dikirim menuju server oleh mikrokontroler ESP32s. Pengiriman data menggunakan modul Wi-Fi ke server Node-RED. Data dari hasil pembacaan sensor diolah dengan metode fuzzy logic Sugeno untuk mendapatkan keluaran jenis penyiraman memiliki nilai rata-rata error $0.573728 \%$, semua data pada server ditampilkan pada web server dashboard Node-RED dalam bentuk teks, grafik dan juga kondisi waktu nyata.
\end{abstract}

Kata Kunci: Firebase, Fuzzy Logic, MQTT, Node-RED, Penyiraman Otomatis

\begin{abstract}
ITERA is a campus with the slogan smart, friendly and forest campus. A green campus (forest campus) can be realized by regularly watering the plants. When watering these plants is not sufficient, the plants will wither and die, but excessive water also causes the plants to not grow due to rot of the plant roots. An automatic watering system that can monitor plant environmental conditions using the MQTT protocol can be designed as a system that can monitor plant environmental conditions remotely and in real time. This system is made using the DHTI1 sensor which functions to read temperature and also the YL69 sensor which functions to read soil moisture. DHT11 reads the temperature with a value between 0 - $50 \mathrm{C}$ with an average error value of $2.22 \%$. The higher the temperature sensor output value, the hotter the temperature will be, if the temperature sensor output value gets lower, the temperature will get colder. The YL-69 sensor can read the value of soil moisture which has a range between 0-1023 with an average error value of 11.09\%. The higher the soil moisture sensor output value, the drier the soil conditions will be, if the soil moisture sensor output value is lower, the soil conditions will be more humid. The sensor is sent to the server by the ESP32s microcontroller. Sending data using the Wi-Fi module to the Node-RED server. The data from the sensor readings are processed using the Sugeno fuzzy logic method to get the watering type output which has an average error value of $0.573728 \%$, all data on the server is displayed on the Node-RED dashboard web server in the form of text, graphics and also real time conditions.
\end{abstract}

Keywords: Automatic Watering, Firebase, Fuzzy Logic. MQTT, Node-RED

\section{PENDAhUluan}

A ir merupakan salah satu unsur yang dibutuhkan tanaman untuk dapat berfotosintesis agar bisa bertahan hidup [1]. Kebutuhan air yang cukup menjadikan tanah yang subur, sehingga tanaman dapat berkembang dengan baik, namun air yang berlebihan juga menyebabkan tanaman tidak dapat tumbuh karena terjadi pembusukan pada akar tanaman. Kebutuhan volume air pada tanaman yaitu sekitar $1-2$ liter air [2]. Adapun tingkat kesuburan dapat dipengaruhi dari kelembaban tanah (intensitas air) yang dikandungnya. Salah satu cara agar tanah memiliki tingkat kesuburan yang baik dengan melakukan penyiraman. Namun, saat ini masih ada kekurangan dalam penyiraman yaitu penyiraman yang dilakukan secara manual [3]. Penyiraman secara manual membutuhkan tenaga, dan waktu yang lama. 
Penyiraman merupakan salah satu faktor terpenting pada tanaman untuk keberlangsungan hidup tanaman tersebut. Penyiraman dapat dilakukan secara alami atau buatan. Hujan merupakan penyiraman alami, dimana hujan adalah proses kondensasi uap air di atmosfer menjadi butir air yang cukup berat untuk jatuh.

Menurut sumber dari staf Administrasi Umum Unit Pelaksana Teknis Kawasan dan K3 - Divisi Lahan di Institut Teknologi Sumatera (2019), diketahui penyiraman tanaman di taman sekitar gedung C dan gedung D dilakukan setiap hari dengan satu kali penyiraman dalam sehari yang dilakukan pada pagi hari atau sore hari. Penyiraman yang dilakukan tidak memiliki volume air yang tetap tetapi harus dengan kapasitas lapang. Kapasitas lapang adalah kadar air yang dapat disimpan oleh suatu tanah dalam keadaan masih dipengaruhi gravitasi bumi [4]. Proses penyiraman dengan volume air yang tidak menentu dapat mengakibatkan tanaman akan kekurangan air dan tidak dapat melakukan fotosintesis serta kemungkinan terbesar akan mati. Penyiraman pada taman tersebut yang dilakukan oleh manusia akan membutuhkan biaya, waktu dan tenaga. Oleh karena itu, belum diterapkannya penyiraman yang dilakukan secara otomatis dan dapat dikendalikan jarak jauh.

Upaya yang dilakukan untuk melakukan penyiraman secara efisien terus ditingkatkan [1], salah satunya mengembangkan sistem untuk penyiraman secara otomatis. Kemajuan teknologi saat ini memungkinkan pengawas untuk segera mengetahui kondisi tanaman secara jarak jauh jika keadaannya kering dan perlu disiram. Salah satu teknologi yang dapat digunakan adalah Internet of Things (IoT). IoT merupakan sebuah konsep yang bertujuan untuk memperluas pemanfaatan internet yang terhubung dengan perangkat yang dapat melakukan pertukaran data dan melakukan kendali jarak jauh terhadap perangkat melalui jaringan Internet [5]. Adapun semua perangkat fisik maupun virtual dapat dipantau dan dikendalikan dari jarak jauh menggunakan Internet. Salah satu kegunaan IoT adalah untuk mengakses dan mengambil data dari suatu tempat dengan menggunakan sensor.

\section{TINJAUAN PUSTAKA}

\section{A. Sistem Penyiraman Otomatis}

Sistem penyiraman otomatis merupakan sistem yang dapat memantau kondisi lingkungan tanaman dengan menggunakan protokol MQTT dapat dirancang sebagai sistem yang dapat memantau kondisi lingkungan tanaman secara jarak jauh dan waktu nyata. Sistem ini dibuat menggunakan sensor suhu dan sensor kelembaban tanah.

Sistem tersebut akan menyiram secara otomatis pada waktu yang telah ditentukan dengan menggunakan logika fuzzy Sugeno yang menghasilkan keluaran lamanya penyiraman sesuai dengan kondisi tanaman.

\section{B. Mikrokontroler dan Sensor}

Mikrokontroler adalah sebuah alat dalam satu chip (Single Chip) IC [6]. Mikrokontroler dapat mengerjakan satu atau be- berapa tugas yang sangat spesifik. Elemen yang terdapat pada mikrokontroler yaitu pemroses (processor), memori, masukan dan keluaran. Mikrokontroler NodeMCU ESP32s memiliki modul WiFi dan modul Bluetooth dikhususkan untuk "Connected to Internet" pada IoT [7].

Pada penelitian ini menggunakan dua jenis sensor sebagai berikut:

1) Sensor Suhu

Sensor suhu DHT11 adalah sensor yang berfungsi untuk mengetahui temperatur suatu lingkungan dengan mengubah besaran panas menjadi besaran listrik yang dapat dengan mudah dianalisis besarnya, memiliki komponen elektronika yang berfungsi untuk mengubah perubahan temperatur yang diterima dalam perubahan besaran elektrik [8]. DHT11 dapat mendeteksi suhu dengan rentang temperatur antara $0-50^{\circ} \mathrm{C}$ dengan kesalahan $\pm 2{ }^{\circ} \mathrm{C}$.

2) Sensor Kelembaban Tanah

Sensor kelembaban tanah YL-69 adalah sensor yang mampu mendeteksi intensitas air di dalam tanah (moisture) [9]. Sensor ini terdiri dua probe untuk melewatkan arus melalui tanah, dan membaca resistansinya untuk mendapatkan nilai tingkat kelembaban. Sensor YL-69 membaca nilai kelembaban tanah yang berbanding terbalik. Semakin sedikit air membuat tanah lebih sulit menghantarkan listrik (resistansi besar), sedangkan tanah yang basah sangat mudah menghantarkan listrik (resistansi kecil).

\section{Server}

Server merupakan komputer yang berperan sebagai menerima permintaan (request) layanan dari client [10]. Client yang meminta layanan pada server akan dilayani oleh komputer server. Server juga dapat mengirimkan permintaan layanan ke client atau layanan online. Server menerima permintaan layanan melalui broker, sedangkan server mengirimkan permintaan layanan melalui broker atau API. Pada server terdapat Node-RED yang dikembangkan oleh IBM Emerging Technology dan komunitas open source sebagai tool berbasis browser dengan pemrograman visual menggunakan flow [11]. Dalam flow Node-RED ter- dapat node pemrograman yang saling terhubung dengan node lain. Jenis-jenis node pada Node-RED diantaranya node input, node output serta node proses yang membuat flow untuk memproses data, mengontrol dan mengirimkan peringatan. Dibutuh- kan NodeJS untuk menjalankan Node-RED. Salah satu fitur Node-RED yaitu modul Node-RED Dashboard yang dapat mem- 
buat dashboard data secara langsung.

\section{Fuzzy Logic}

Logika fuzzy adalah suatu proses pengambilan keputusan berbasis aturan yang bertujuan untuk memecahkan masalah mengenai ketidakpastian, dimana sistem tersebut dirancang untuk mengontrol keluaran tunggal yang berasal dari beberapa masukan yang tidak saling berhubungan. Dalam teori sistem fuzzy dikenal suatu konsep sistem fuzzy yang digunakan dalam proses prediksi pada umumnya terdiri atas empat tahap, yaitu tahap fuzzification, tahap pembentukan rule basis fuzzy, tahap interferensi dan tahap defuzzification. Tahap fuzzification yaitu suatu proses untuk mengubah suatu masukan dari bentuk tegas (crisp) menjadi fuzzy (variabel linguistik). Tahap pembentukan rule basis fuzzy yaitu tahapan membuat aturan yang akan digunakan pada fuzzy. Tahap inferensi yaitu suatu kaidah atau aturan fuzzy untuk menghasilkan output dari tiap aturan. Tahap defuzzification yaitu suatu proses perhitungan dari keluaran bentuk tegas (crisp output).

Terdapat beberapa metode memprediksi pada sistem fuzzy yang salah satu metodenya adalah metode Sugeno, metode yang diusulkan oleh Michio Sugeno hampir sama dengan metode Mamdani hanya saja output (konsekuen) bukan merupakan him- punan fuzzy tetapi berupa konstanta atau persamaan linier. Penggunaan singleton sebagai fungsi keanggotaan dari konsekuen. Singleton merupakan sebuah himpunan fuzzy yang memiliki fungsi keanggotaan tertentu yang mempunyai sebuah nilai dalam rentang antara 0 sampai 1 [12]. Fungsi keanggotaan pada fuzzy logic adalah suatu kurva yang menunjukkan pemetaan titik- titik input data ke dalam nilai keanggotaannya (derajat keanggotaan) yang memiliki interval nilai antara 0 sampai 1 [13]. Terdapat 2 fungsi keanggotaan yang dapat digunakan yaitu fungsi keanggotaan segitiga dan fungsi keanggotaan trapesium. Fungsi keanggotaan segitiga terdapat 3 parameter $(\mathrm{a}, \mathrm{b}, \mathrm{c})$ yang akan menentukan koordinat $\mathrm{x}$ dari 3 sudut. Kurva segitiga merupakan gabungan antara dua garis (linier) yang memiliki nilai keanggotaan 1 pada titik sudut bagian atas segitiga. Fungsi keanggotaan trapesium terdapat 4 parameter $(\mathrm{a}, \mathrm{b}, \mathrm{c}, \mathrm{d})$ yang akan menentukan koordinat $\mathrm{x}$ dari 4 sudut. Kurva trapesium hampir sama dengan kurva segitiga, hanya terdapat titik yang memiliki nilai keanggotaan 1.

\section{Metode PENELITIAN}

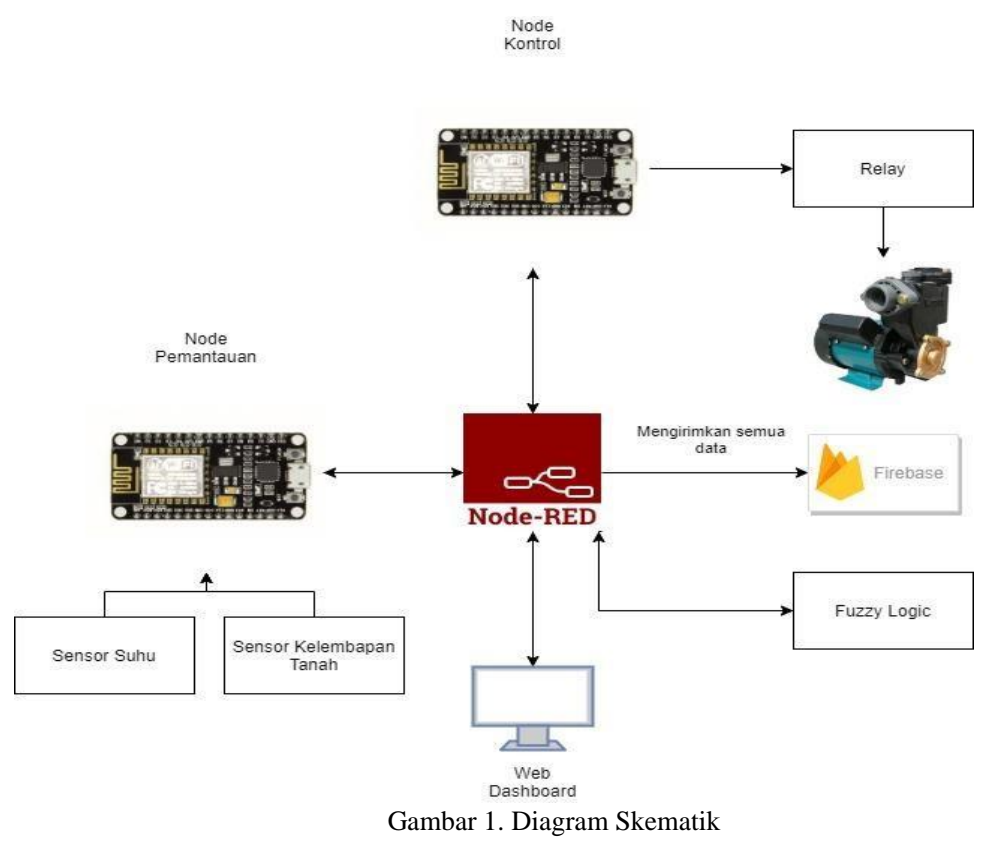

Pada Gambar 1 sistem penyiraman otomatis menggunakan sensor suhu dan sensor kelembaban tanah yang dapat mendeteksi suhu, kelembaban udara dan kelembaban tanah. Sensor tersebut terhubung dengan mikrokontroler yang bertugas mengirimkan data menuju server dengan metode MQTT. Pada server data hasil deteksi sensor akan diolah dengan menggunakan fuzzy logic dengan parameter nilai dari hasil deteksi suhu dan kelembaban tanah untuk mendapatkan output penyiraman tanaman terbaik. Data yang sudah diolah dengan menggunakan fuzzy logic dan data hasil deteksi sensor akan dikirimkan ke Firebase.

Terdapat 4 (empat) tahapan pada fuzzy logic Sugeno untuk penyiraman otomatis [12] tahapan tersebut diantaranya:

\section{A. Tahap Fuzzyfication}

Pada tahap fuzzification mengubah data masukan suhu dan kelembaban tanah dari bentuk tegas (crisp) menjadi bentuk fuzzy (variabel linguistik). Terdapat data suhu [14] dan data kelembaban tanah [15] yang akan diubah 
menjadi bentuk fuzzy. Tahap pengubahan tersebut dapat dilihat pada Tabel 1.

Tabel 1. Tahap Fuzzyfication

\begin{tabular}{|l|c|}
\hline \multicolumn{2}{|c|}{ Definisi Dan Nilai Parameter } \\
\hline Masukan & Variabel fuzzy \\
\hline Suhu pada lingkungan & Suhu (S) \\
\hline $10-25^{\circ} \mathrm{C}$ & Dingin (D) \\
\hline $25-35^{\circ} \mathrm{C}$ & Normal (N) \\
\hline $35-50^{\circ} \mathrm{C}$ & Panas (P) \\
\hline Kelembaban tanah pada lingkungan & Basah (B) \\
\hline $150-339$ & Lembap (L) \\
\hline $340-475$ & Kering (K) \\
\hline $476-1023$ & \\
\hline
\end{tabular}

\section{B. Tahap Pembentukan Rule Basis Fuzzy}

Tahap pembentukan rule basis fuzzy yaitu pembentukan rule yang digunakan untuk mengolah data fuzzy, terdapat 2 data masukan yaitu suhu dan kelembaban yang masing-masing memiliki 3 buah variabel. Maka terdapat 9 rule basis fuzzy logic diantaranya:

1. Suhu Dingin dan Kelembaban Tanah Basah.

2. Suhu Dingin dan Kelembaban Tanah Lembap.

3. Suhu Dingin dan Kelembaban Tanah Kering.

4. Suhu Normal dan Kelembaban Tanah Basah.

5. Suhu Normal dan Kelembaban Tanah Lembap.

6. Suhu Normal dan Kelembaban Tanah Kering.

7. Suhu Panas dan Kelembaban Tanah Basah.

8. Suhu Panas dan Kelembaban Tanah Lembap.

9. Suhu Panas dan Kelembaban Tanah Kering.

\section{Tahap Inferensi}

Tahap inferensi suatu kaidah/aturan/rule fuzzy untuk menghasilkan output dari tiap rule. Terdapat 4 hasil keluaran fuzzy logic dengan rentang nilai 0 sampai 1 [16]. Hasil keluaran pada penyiraman otomatis yaitu Tidak Siram, Siram Sebentar, Siram Normal, dan Siram Lama yang memiliki nilai yaitu:

1. Suhu Dingin dan Kelembaban Tanah Basah.

2. Suhu Dingin dan Kelembaban Tanah Lembap.

3. Suhu Dingin dan Kelembaban Tanah Kering.

4. Suhu Normal dan Kelembaban Tanah Basah.

5. Suhu Normal dan Kelembaban Tanah Lembap.

6. Suhu Normal dan Kelembaban Tanah Kering.

7. Suhu Panas dan Kelembaban Tanah Basah.

8. Suhu Panas dan Kelembaban Tanah Lembap.

9. Suhu Panas dan Kelembaban Tanah Kering.

D. Tahap Defuzzyfication

Tahap defuzzification suatu proses perhitungan dari keluaran bentuk tegas (crisp output). Pada metode Sugeno menggunakan perhitungan Weight Average (WA) dapat dilihat pada Persamaan 1:

Keterangan:

$$
W A=\frac{\sum_{n}^{9}=1 \alpha_{n} z_{n}}{\Sigma_{n}^{9}=1 \alpha_{n} z_{n}}
$$

$W A=$ nilai rata-rata terbobot

$a_{n}=a-$ predikat ke-i

$z_{n}=$ Konsekuen ke- $i$

\section{HASIL DAN PEMBAHASAN}

Pengujian terhadap keakuratan sensor suhu DHT11 dibandingkan dengan termometer ruangan raksa (Wall Termometer). Berikut hasil dari perbandingan sensor DHT11 dan termometer ruangan raksa pada Tabel 2. 
Wijaya, Hanifah, dan Manullang — Purwarupa Penyiraman Otomatis Dengan Arsitektur Mqtt Dan Logika Fuzzy Sugeno Untuk Meningkatkan Keefektifan Manajemen Penyiraman Tanaman (Studi Kasus : Itera)

Tabel 2. Hasil Pengujian Keakuratan Sensor Suhu

\begin{tabular}{|c|c|c|c|c|c|}
\hline No & Waktu & Sensor DHT11 & Termometer Ruangan Raksa & \multicolumn{2}{|c|}{ Error } \\
\hline 1. & Minggu, 16 Agustus 2020 12:04:00 & $31.00^{\circ} \mathrm{C}$ & $30^{\circ} \mathrm{C}$ & $1{ }^{\circ} \mathrm{C}$ & $3.33 \%$ \\
\hline 2. & Minggu, 16 Agustus 2020 12:04:30 & $31.00^{\circ} \mathrm{C}$ & $30^{\circ} \mathrm{C}$ & $1{ }^{\circ} \mathrm{C}$ & $3.33 \%$ \\
\hline 3. & Minggu, 16 Agustus 2020 12:05:00 & $31.00^{\circ} \mathrm{C}$ & $30^{\circ} \mathrm{C}$ & $1{ }^{\circ} \mathrm{C}$ & $3.33 \%$ \\
\hline 4. & Minggu, 16 Agustus 2020 12:05:30 & $31.00{ }^{\circ} \mathrm{C}$ & $30^{\circ} \mathrm{C}$ & $1{ }^{\circ} \mathrm{C}$ & $3.33 \%$ \\
\hline 5. & Minggu, 16 Agustus 2020 12:06:00 & $31.00^{\circ} \mathrm{C}$ & $30^{\circ} \mathrm{C}$ & $1{ }^{\circ} \mathrm{C}$ & $3.33 \%$ \\
\hline 6. & Minggu, 30 Agustus 2020 17:10:00 & $29.00{ }^{\circ} \mathrm{C}$ & $29^{\circ} \mathrm{C}$ & $0^{\circ} \mathrm{C}$ & $0 \%$ \\
\hline 7. & Minggu, 30 Agustus 2020 18:10:00 & $29.00^{\circ} \mathrm{C}$ & $29^{\circ} \mathrm{C}$ & $0{ }^{\circ} \mathrm{C}$ & $0 \%$ \\
\hline 8. & Minggu, 30 Agustus 2020 19:10:00 & $29.00^{\circ} \mathrm{C}$ & $29^{\circ} \mathrm{C}$ & $0^{\circ} \mathrm{C}$ & $0 \%$ \\
\hline 9. & Minggu, 30 Agustus 2020 20:10:00 & $29.00^{\circ} \mathrm{C}$ & $28^{\circ} \mathrm{C}$ & $1{ }^{\circ} \mathrm{C}$ & $3.33 \%$ \\
\hline 10. & Minggu, 30 Agustus 2020 21:10:00 & $29.00^{\circ} \mathrm{C}$ & $28^{\circ} \mathrm{C}$ & $1{ }^{\circ} \mathrm{C}$ & $3.33 \%$ \\
\hline 11. & Senin, 31 Agustus 2020 09:15:00 & $28.00^{\circ} \mathrm{C}$ & $28^{\circ} \mathrm{C}$ & $0^{\circ} \mathrm{C}$ & $0 \%$ \\
\hline 12. & Senin, 31 Agustus 2020 10:15:00 & $29.00^{\circ} \mathrm{C}$ & $29^{\circ} \mathrm{C}$ & $0^{\circ} \mathrm{C}$ & $0 \%$ \\
\hline 13. & Senin, 31 Agustus 2020 11:15:00 & $31.00^{\circ} \mathrm{C}$ & $30^{\circ} \mathrm{C}$ & $1{ }^{\circ} \mathrm{C}$ & $3.33 \%$ \\
\hline 14. & Senin, 31 Agustus 2020 12:15:00 & $32.00^{\circ} \mathrm{C}$ & $31^{\circ} \mathrm{C}$ & $1{ }^{\circ} \mathrm{C}$ & $3.33 \%$ \\
\hline \multirow[t]{2}{*}{15.} & Senin, 31 Agustus 2020 13:15:00 & $32.00^{\circ} \mathrm{C}$ & $31^{\circ} \mathrm{C}$ & $1{ }^{\circ} \mathrm{C}$ & $3.33 \%$ \\
\hline & \multicolumn{3}{|c|}{ Rata-rata } & $0.6667^{\circ} \mathrm{C}$ & $2.22 \%$ \\
\hline
\end{tabular}

Pengujian terhadap keakuratan sensor kelembaban tanah YL-69 dibandingkan dengan Soil Analyzer. Berikut hasil dari perbandingan sensor YL-69 dan Soil Analyzer pada Tabel 3.

Tabel 3. Hasil Pengujian Keakuratan Sensor Kelembaban Tanah

\begin{tabular}{|c|l|c|c|c|c|}
\hline No & \multicolumn{1}{|c|}{ Waktu } & Sensor YL-69 & Soil Analyzer & \multicolumn{2}{c|}{ Error } \\
\hline 1. & Minggu, 16 Agustus 2020 12:04:00 & 803.25 & 900 & 96.75 & $10.75 \%$ \\
\hline 2. & Minggu, 16 Agustus 2020 12:04:30 & 805.75 & 900 & 94.25 & $10.47222 \%$ \\
\hline 3. & Minggu, 16 Agustus 2020 12:05:00 & 800.5 & 900 & 99.5 & $11.05556 \%$ \\
\hline 4. & Minggu, 16 Agustus 2020 12:05:30 & 807.25 & 900 & 92.75 & $10.30556 \%$ \\
\hline 5. & Minggu, 16 Agustus 2020 12:06:00 & 806.25 & 900 & 93.75 & $10.41667 \%$ \\
\hline 6. & Minggu, 30 Agustus 2020 17:10:00 & 467.75 & 500 & 32.25 & $6.45 \%$ \\
\hline 7. & Minggu, 30 Agustus 2020 18:10:00 & 475.25 & 500 & 24.75 & $4.95 \%$ \\
\hline 8. & Minggu, 30 Agustus 2020 19:10:00 & 460.00 & 500 & 40 & $8 \%$ \\
\hline 9. & Minggu, 30 Agustus 2020 20:10:00 & 447.75 & 500 & 52.25 & $10.45 \%$ \\
\hline 10. & Minggu, 30 Agustus 2020 21:10:00 & 368.25 & 400 & 31.75 & $7.9375 \%$ \\
\hline 11. & Senin, 31 Agustus 2020 09:15:00 & 368.25 & 400 & 31.75 & $7.9375 \%$ \\
\hline 12. & Senin, 31 Agustus 2020 10:15:00 & 423.75 & 500 & 76.25 & $15.25 \%$ \\
\hline 13. & Senin, 31 Agustus 2020 11:15:00 & 418.25 & 500 & 81.75 & $16.35 \%$ \\
\hline 14. & Senin, 31 Agustus 2020 12:15:00 & 412 & 500 & 88 & $17.6 \%$ \\
\hline 15. & Senin, 31 Agustus 2020 13:15:00 & 407.25 & 500 & 92.75 & $18.55 \%$ \\
\hline & \multicolumn{2}{|c|}{ Rata-rata } & 68.56 & $11.09 \%$ \\
\hline
\end{tabular}

Berdasarkan pengujian keakuratan sensor pada Tabel 2 dan Tabel 3, sensor suhu DHT11 dibandingkan dengan termometer ruangan raksa memiliki nilai error keakuratan sensor sebesar $0.6667{ }^{\circ} \mathrm{C}$ atau $2.22 \%$ dan sensor kelembaban tanah YL-69 dibandingkan dengan termometer ruangan raksa memiliki nilai error keakuratan sensor sebesar 68.56 atau $11.09 \%$.

Pada pengujian ini menguji nilai dari kondisi data suhu dan data kelembaban tanah yang diolah dengan fuzzy logic Sugeno dibandingkan dengan MATLAB.

Kondisi variabel suhu terdapat 5 rentang kategori yaitu :
1) Dingin
$: 18(10-25)$
2) Dingin - Normal
$: 28(25-30)$
3) Normal
$: 33(30-35)$
4) Normal Panas
$: 38(35-40)$
5) Panas
: $45(40-50)$

Kondisi variabel kelembaban tanah terdapat 5 rentang kategori yaitu
1) Basah
: $245(150-340)$
2) Basah - Lembap
: $390(340-440)$
3) Lembap
: $458(440-475)$
4) Lembap - Kering
: $525(475-575)$
5) Kering
: $799(575-1023)$ 
Hasil perbandingan antara nilai fuzzy logic antara MATLAB dengan sistem dapat dilihat Tabel 4.

Tabel 4. Hasil Pengujian Keakuratan Fuzzy Logic

\begin{tabular}{|c|c|c|c|c|c|c|}
\hline No & Suhu & Kelembaban Tanah & $\begin{array}{l}\text { Fuzzy Logic } \\
\text { Sistem }\end{array}$ & $\begin{array}{c}\text { Fuzzy Logic } \\
\text { MATLAB }\end{array}$ & \multicolumn{2}{|c|}{ Error } \\
\hline 1. & 18 & 245 & 0 & 0 & 0 & $0 \%$ \\
\hline 2. & 18 & 390 & 0.16665 & 0.165 & 0.00165 & $1 \%$ \\
\hline 3. & 18 & 458 & 0.3333 & 0.33 & 0.0033 & $1 \%$ \\
\hline 4. & 18 & 525 & 0.5 & 0.5 & 0 & $0 \%$ \\
\hline 5. & 18 & 799 & 0.6667 & 0.67 & 0.0033 & $0.492537 \%$ \\
\hline 6. & 28 & 245 & 0 & 0 & 0 & $0 \%$ \\
\hline 7. & 28 & 390 & 0.2592611111111111 & 0.267 & 0.007739 & $2.898502 \%$ \\
\hline 8. & 28 & 458 & 0.5333399999999999 & 0.534 & 0.00066 & $0.123596 \%$ \\
\hline 9. & 28 & 525 & 0.6851944444444444 & 0.701 & 0.015806 & $2.254779 \%$ \\
\hline 10. & 28 & 799 & 0.8666799999999999 & 0.868 & 0.00132 & $0.152074 \%$ \\
\hline 11. & 33 & 245 & 0 & 0 & 0 & $0 \%$ \\
\hline 12. & 33 & 390 & 0.33335 & 0.335 & 0.00165 & $0.492537 \%$ \\
\hline 13. & 33 & 458 & 0.6667 & 0.67 & 0.0033 & $0.492537 \%$ \\
\hline 14. & 33 & 525 & 0.83335 & 0.835 & 0.00165 & $0.197605 \%$ \\
\hline 15. & 33 & 799 & 1 & 1 & 0 & $0 \%$ \\
\hline 16. & 38 & 245 & 0.19998 & 0.198 & 0.00198 & $1 \%$ \\
\hline 17. & 38 & 390 & 0.42593333333333333 & 0.434 & 0.008067 & $1.858756 \%$ \\
\hline 18 & 38 & 458 & 0.6667 & 0.67 & 0.0033 & $0.492537 \%$ \\
\hline 19. & 38 & 525 & 0.8333499999999999 & 0.835 & 0.00165 & $0.197605 \%$ \\
\hline 20. & 38 & 799 & 1 & 1 & 0 & $0 \%$ \\
\hline 21. & 45 & 245 & 0.3333 & 0.33 & 0.0033 & $1 \%$ \\
\hline 22. & 45 & 390 & 0.5 & 0.5 & 0 & $0 \%$ \\
\hline 23. & 45 & 458 & 0.6667 & 0.67 & 0.0033 & $0.492537 \%$ \\
\hline 24. & 45 & 525 & 0.83335 & 0.835 & 0.00165 & $0.197605 \%$ \\
\hline 25. & 45 & 799 & 1 & 1 & 0 & $0 \%$ \\
\hline \multicolumn{5}{|c|}{ Rata-rata } & 0.002545 & $0.573728 \%$ \\
\hline
\end{tabular}

Berdasarkan tabel pada Tabel 4 diatas, pengujian keakurasian fuzzy logic sistem dengan fuzzy logic MATLAB yang dilakukan pada semua kondisi suhu dan kelembaban tanah. Pada pengujian tersebut didapat nilai rata-rata kesalahan 0.002545 atau 0.573728 $\%$. Implementasi fuzzy logic pada kondisi nyata dapat dilihat pada Tabel 5.

Tabel 5. Hasil Implementasi Fuzzy Logic Pada Sistem

\begin{tabular}{|c|l|c|c|c|c|c|}
\hline No & \multicolumn{1}{|c|}{ Waktu } & Suhu & $\begin{array}{c}\text { Kelembaban } \\
\text { Tanah }\end{array}$ & Jenis Siram & $\begin{array}{c}\text { Kondisi } \\
\text { Pompa }\end{array}$ & Keterangan \\
\hline 1. & Rabu, 22 Juli 2020 17:00:04 & $28.00^{\circ} \mathrm{C}$ & 674.75 & Banyak & Mati & Tidak Menyiram \\
\hline 2. & Rabu, 22 Juli 2020 17:00:09 & $28.00{ }^{\circ} \mathrm{C}$ & 676.75 & Banyak & Mati & Tidak Menyiram \\
\hline 3. & Rabu, 22 Juli 2020 17:00:14 & $28.00{ }^{\circ} \mathrm{C}$ & 698 & Banyak & Mati & Tidak Menyiram \\
\hline 4. & Rabu, 22 Juli 2020 17:00:19 & $28.00^{\circ} \mathrm{C}$ & 667 & Banyak & Mati & Tidak Menyiram \\
\hline 5. & Rabu, 22 Juli 2020 17:00:24 & $28.00^{\circ} \mathrm{C}$ & 683.25 & Banyak & Mati & Tidak Menyiram \\
\hline 6. & Minggu, 30 Agustus 2020 17:10:00 & $29.00^{\circ} \mathrm{C}$ & 467.75 & Normal & Mati & Tidak Menyiram \\
\hline 7. & Minggu, 30 Agustus 2020 18:10:00 & $29.00^{\circ} \mathrm{C}$ & 475.25 & Normal & Mati & Tidak Menyiram \\
\hline 8. & Minggu, 30 Agustus 2020 19:10:00 & $29.00^{\circ} \mathrm{C}$ & 460.00 & Normal & Mati & Tidak Menyiram \\
\hline 9. & Minggu, 30 Agustus 2020 20:10:00 & $29.00^{\circ} \mathrm{C}$ & 447.75 & Normal & Mati & Tidak Menyiram \\
\hline 10. & Minggu, 30 Agustus 2020 21:10:00 & $29.00^{\circ} \mathrm{C}$ & 368.25 & Tidak Siram & Mati & Tidak Menyiram \\
\hline 11. & Senin, 31 Agustus 2020 09:15:00 & $28.00{ }^{\circ} \mathrm{C}$ & 368.25 & Tidak Siram & Mati & Tidak Menyiram \\
\hline 12. & Senin, 31 Agustus 2020 10:15:00 & $29.00^{\circ} \mathrm{C}$ & 423.75 & Normal & Mati & Tidak Menyiram \\
\hline 13. & Senin, 31 Agustus 2020 11:15:00 & $31.00^{\circ} \mathrm{C}$ & 418.25 & Normal & Mati & Tidak Menyiram \\
\hline 14. & Senin, 31 Agustus 2020 12:15:00 & $32.00{ }^{\circ} \mathrm{C}$ & 412 & Normal & Mati & Tidak Menyiram \\
\hline 15. & Senin, 31 Agustus 2020 13:15:00 & $32.00^{\circ} \mathrm{C}$ & 407.25 & Normal & Mati & Tidak Menyiram \\
\hline
\end{tabular}


Wijaya, Hanifah, dan Manullang — Purwarupa Penyiraman Otomatis Dengan Arsitektur Mqtt Dan Logika Fuzzy Sugeno

Untuk Meningkatkan Keefektifan Manajemen Penyiraman Tanaman (Studi Kasus : Itera)

Berdasarkan Tabel 5, metode fuzzy logic akan memproses setiap data yang masuk pada sistem. Penyiraman otomatis dilakukan setiap hari pada pukul 06.00 dan 17.00. Tampilan antarmuka sistem penyiraman otomatis pada server Node-RED memiliki dua tab yaitu Home Monitoring dan Home Controlling dapat dilihat pada Gambar 2 dan Gambar 3.

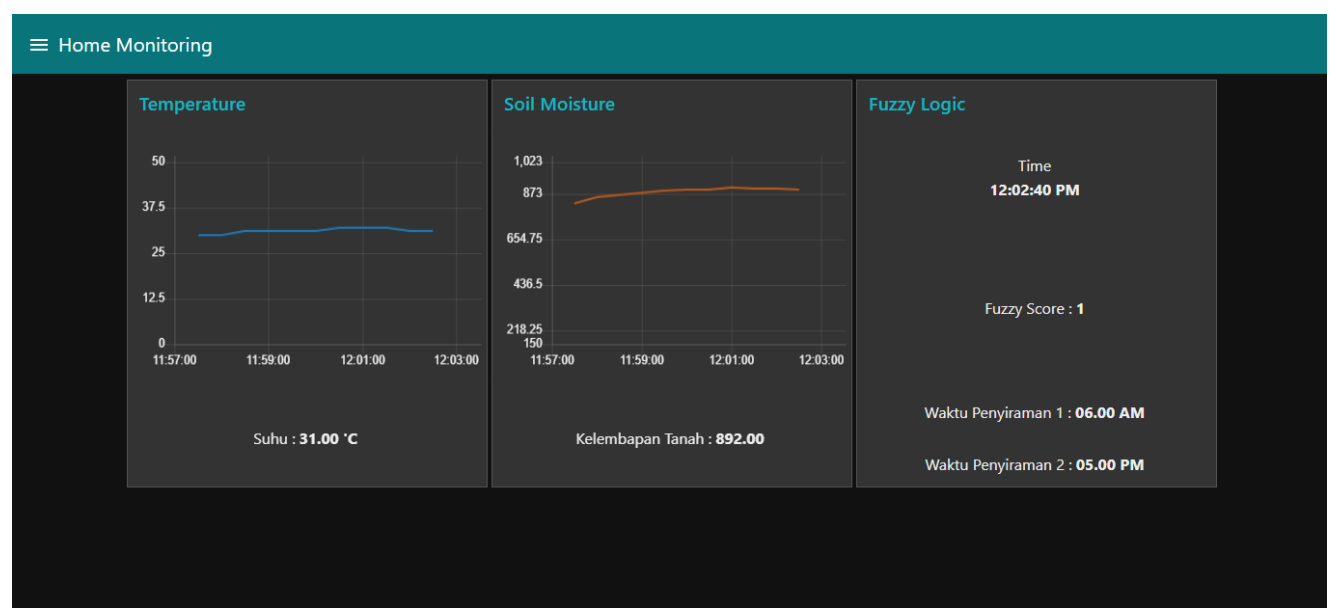

Gambar 2. Tampilan Antarmuka Tab Home Monitoring

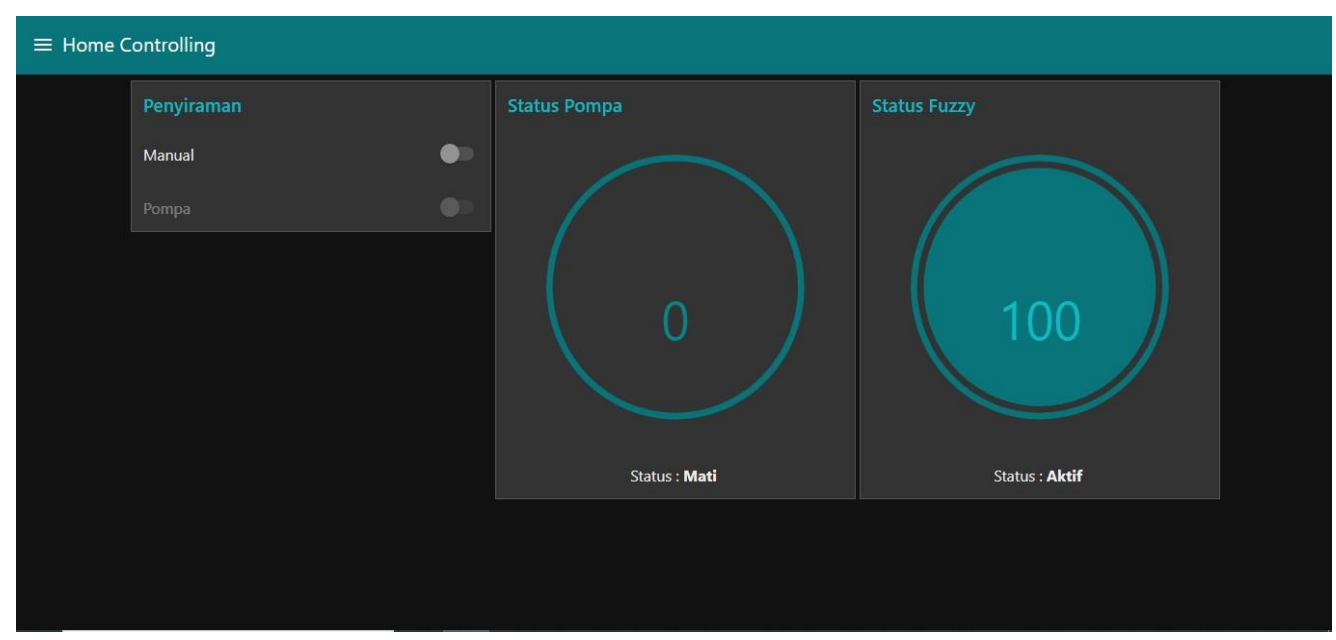

Gambar 3. Tampilan Antarmuka Tab Home Controlling

Pada Gambar 2 merupakan tab untuk konfigurasi antarmuka Monitoring yang memiliki fungsi yaitu menampilkan hasil pemantauan suhu dan kelembaban tanah dari alat pemantauan yang dikirimkan menggunakan MQTT, menampilkan data fuzzy logic hasil pemantauan yang di proses menggunakan fuzzy logic Sugeno dan menampilkan jam dan waktu penyiraman tanaman. Tab Monitoring terdapat visualisasi hasil deteksi dari sensor suhu dan kelembaban tanah serta visualisasi hasil fuzzy logic secara waktu nyata. Visualisasi sensor suhu menggunakan Node Line Chart dan visualisasi sensor kelembaban menggunakan Node Line Chart serta terdapat Node Text yang menjelaskan nilai dari hasil deteksi sensor pada masing-masing sensor. Visualisasi fuzzy logic menggunakan Node Text yang menampilkan nilai dari fuzzy score dan terdapat visualisasi jam serta waktu penyiraman tanaman menggunakan Node Text.

Pada Gambar 3 merupakan tab untuk konfigurasi antarmuka Controlling yang memiliki fungsi yaitu menampilkan status fuzzy logic, menampilkan status power pompa dan menampilkan switch manual yang menghidupkan switch power pompa. Tab Controlling terdapat visualisasi status fuzzy, status pompa dan mode penyiraman manual. Visualisasi pada status fuzzy menggunakan Node Gauge type Level yang menunjukkan kondisi pompa dan Node Text yang menjelaskan kondisi pompa. Terdapat 2 nilai pada Node Gauge type Level yaitu nilai 0 (Tidak Aktif) dan nilai 100 (Aktif). Visualisasi pada status pompa menggunakan Node Gauge type Level yang menunjukkan kondisi pompa dan Node Text yang menjelaskan kondisi pompa. Terdapat 2 nilai pada Node Gauge type Level yaitu nilai 0 (Mati) dan nilai 100 (Hidup). Visualisasi pada penyiraman menggunakan switch, jika switch Manual dihidupkan akan mengaktifkan switch Pompa dan jika switch Manual dimatikan akan menonaktifkan switch Pompa. Switch Pompa jika dalam kondisi dihidupkan akan menyalakan pompa dan kondisi dimatikan akan mematikan pompa. 


\section{KESIMPULAN}

Dari hasil pengujian didapatkan kesimpulan sebagai berikut:

A. Perangkat penyiraman otomatis dengan suhu dan kelembaban tanah pada lahan ITERA Menggunakan Protokol MQTT dapat dirancang menggunakan sensor DHT11 yang berfungsi untuk membaca nilai dari suhu memiliki rata- rata nilai error $2.22 \%$ dan soil moisture YL-69 sensor untuk mendeteksi kelembaban tanah lingkungan memiliki rata- rata nilai error $11.09 \%$. ESP32s berfungsi untuk mengirim data yang dibaca oleh sensor untuk ditampilkan pada web server Node-RED dalam bentuk grafik, dan juga mengatur penyiraman otomatis dengan metode fuzzy logic Sugeno. pengiriman data yang dilakukan oleh modul wifi ESP32s menggunakan protokol MQTT berada pada koneksi jaringan yang sama.

B. Sistem penyiraman otomatis menggunakan web server Node-RED yang dapat mengontrol penyiraman secara jarak jauh dan otomatis menggunakan metode fuzzy logic Sugeno yang memiliki 2 nilai masukkan yaitu nilai suhu dan kelembaban tanah, memiliki 12 rules dan nilai keluaran yaitu lama penyiraman yang dibandingkan dengan MATLAB rata-rata error keluaran yaitu 0.002545 atau $0.573728 \%$.

C. Penggunaan metode fuzzy logic Sugeno memungkinkan penggunaan air dalam penyiraman tanaman. Penggunaan air yang efisien didapat dari cara penyiraman yang memiliki 4 jenis penyiraman yaitu tidak siram (0 liter air), siram sedikit ( \pm 1 liter air), siram normal ( \pm 1.5 liter air), dan siram banyak ( \pm 2 liter air) dimana penyiraman tersebut menggunakan nilai kondisi suhu dan kelembaban tanah lingkungan. Hasil pengujian setelah penyiraman memiliki rata-rata kelembaban tanah menjadi turun $34.65148 \%$ (lebih lembap). Nilai tersebut didapat dari sensor kelembaban tanah YL-69.

\section{DAFTAR PUSTAKA}

[1] P. Setiawan, E. Y. Anggraen, P. Studi, S. Informasi, and S. Kelembaban, "Prorotype Sistem Penyiraman Tanaman Otomatis Terjadwal dan Berbasis Sensor Kelembaban Tanah," IBI DARMAJAYA, pp. 277-283, 2019.

[2] A. T. Maryani, "Pengaruh Volume Pemberian Air Terhadap Pertumbuhan Bibit Kelapa Sawit Di Pembibitan Utama," Fak. Pertan. Univ. Jambi, vol. 1, no. 2, pp. 64-74, 2012.

[3] D. J. M. Erricson Zet Kafiar, Elia Kendek Allo, "Rancang Bangun Penyiram Tanaman Berbasis Arduino Uno Menggunakan Sensor Kelembaban YL-39 Dan YL-69," J. Tek. Elektro dan Komput., vol. 7, no. 3, pp. 267-276, 2018.

[4] I. M. G. Widnyana and I. W. Tika, "Kajian pola titik layu tanaman paprika (Capsicum Annuum L.) dan kapasitas lapang pada beberapa media tanam ( Studi Kasus di Br . Pemuteran Baturiti , Desa Candi Kuning , Kecamatan

Baturiti , Kabupaten Tabanan ). The study of wilting point pattern and fi," J. BETA (BIOSISTEM DAN Tek. PERTANIAN), vol. 5, pp. 146-151, 2017.

[5] O. K. Sulaiman and A. Widarma, "Sistem Internet Of Things ( IoT ) Berbasis Cloud Computing dalam Campus Area Network," Univ. Islam Sumatera utara, no. April, pp. 9-12, 2017.

[6] A. N. N. Chamim, "PENGGUNAAN MICROCONTROLLER SEBAGAI PENDETEKSI POSISI DENGAN MENGGUNAKAN SINYAL GSM," J. Inform., vol. 4, no. 1, pp. 430-439, 2010.

[7] J. Doshi, T. Patel, and S. K. Bharti, "Smart Fanning using IoT, a solution for optimally monitoring fanning conditions," Procedia Comput. Sci., vol. 160, pp. 746-751, 2019.

[8] P. V. Ginting and K. Amdani, "RANCANG BANGUN DETEKTOR SUHU RUANGAN MENGGUNAKAN SENSOR LM35 DENGAN DFRDUINO UNO V3.0 BERBASIS LIQUID CRISTAL DISPLAY (LCD)," J. Einstein, vol. 60, no. 10, pp. 2239-2248, 2004.

[9] Lutfiyana, N. Hudallah, and A. Suryanto, "Rancang Bangun Alat Ukur Suhu Tanah, Kelembaban Tanah, dan Resistansi," J. Tek. Elektro, vol. 9, no. 2, pp. 80-86, 2017.

[10] K. I. Santoso and M. A. Muin, "Implementasi Network Attached Storage ( NAS ) Menggunakan NAS4Free untuk Media Backup File,” Sci. J. Informatics, vol. 2, no. 2, pp. 123-128, 2015.

[11] S. Mulyono, M. Qomaruddin, and M. Syaiful Anwar, "Penggunaan Node-RED pada Sistem Monitoring dan Kontrol Green House berbasis Protokol MQTT," J. Transistor Elektro dan Inform. (TRANSISTOR EI, vol. 3, no. 1, pp. 31- 44, 2018.

[12] Lodewyik Rahakbauw Dorteus, "Penerapan Logika Fuzzy Metode Sugeno Berdasarkan Data Persediaan Dan Jumlah Permintaan ( Studi Kasus: Pabrik Roti Sarinda Ambon ) Application of Fuzzy Logic Method Sugeno To Determine the Total Production of Bread ," J. Ilmu Mat. dan Terap., vol. 9, pp. 121-134, 2015.

[13] H. Harys, I. Suprayogi, and Rinaldi, “APLIKASI LOGIKA FUZZY UNTUK PREDIKSI KEJADIAN HUJAN (Studi Kasus: Sub DAS Siak Hulu)," pp. 9-43, 2013.

[14] I. L. H. D et al., "Penerapan Fuzzy Logic Pada Sistem Pengaturan Jumlah Air Berdasarkan Suhu DanKelembaban," Semin. Nas. Inform. (semnasIF 2011), vol. 3, no. April, pp. 358-365, 2015.

[15] H. Husdi, "Monitoring Kelembaban Tanah Pertanian Menggunakan Soil Moisture Sensor Fc-28 Dan ArduinoUno," Ilk. J. Ilm., vol. 10, no. 2, p. 237, 2018.

[16] A. Farmadi, D. T. Nugrahadi, F. Indriani, and O. Soesanto, "Sistem Fuzzy Logic Tertanam Pada Mikrokontroler Untuk Penyiraman Tanaman Pada Rumah Kaca," Klik - Kumpul. J. Ilmu Komput., vol. 4, no. 2, p. 223, 2017 